\title{
The estimation of serum thyroxine by competitive binding analysis: A modified method
}

\author{
D. J. GOLDIE, R. D. JENNINGS, AND G. K. MCGOWAN \\ From the Department of Chemical Pathology, Bristol Royal Infirmary
}

SYNOPSIS The method of estimating serum thyroxine by competitive binding analysis has beenin examined stage by stage. The extraction procedures recommended by some authors are shown to -7 extract protein as well as thyroxine, and so produce inaccurate results. A modified method is pro- $-\not$ posed which increases accuracy and precision.

The estimation of serum thyroxine $\left(T_{4}\right)$ by the method of 'saturation' or 'competitive binding' analysis has been described by Ekins (1960), Murphy and Pattee (1964), and Murphy (1965). We found that, even in the hands of technicians experienced in the assay, the precision of the method was unsatisfactory and made duplicate analyses necessary. As the work load increased it became necessary to search for a method which gave satisfactory precision using single estimations on each test serum. The method was therefore examined, stage by stage, to define the important variables and reduce them wherever possible.

The basic method as described by Murphy (1965) may be summarized as follows. $\mathrm{T}_{4}$ is extracted from serum at room temperature with 2 volumes of $95 \%$ ethanol. After centrifugation an aliquot of extract is dried down under nitrogen and the precipitate taken up in $1 \mathrm{ml}$ of binding reagent (pooled normal serum diluted with barbital buffer to give a serum concentration of $3 \%$ to which a trace of labelled thyroxine ${ }^{125} \mathrm{IT}_{4}$ is added); the mixture is incubated at $45^{\circ}$ and then allowed to equilibrate at $4^{\circ}$. The bound and free ${ }^{125} \mathrm{IT}_{4}$ fractions are then separated using anion exchange resin, and after dilution with barbital buffer an aliquot of supernatant is taken for counting. A standard curve is set up using unlabelled $\mathrm{T}_{4}$ and the test sera are read against this. Results are expressed as thyroxine iodine $\left(\mathrm{T}_{4} \mathrm{I}\right)$.

\section{Materials and Methods}

RADIOACTIVE THYROXINE

L-thyroxine labelled with ${ }^{125} \mathrm{I}$, dissolved in $50 \%$

Received for publication 23 October 1973. aqueous propylene glycol (twice a month from the Radiochemical Centre, Amersham) and of initiak specific activity $20-40 \mathrm{mc} / \mathrm{mg}$, was diluted on arrival $\vec{\omega}$ to $55 \mu \mathrm{c} / \mathrm{ml}$ with $50 \%$ propylene glycol and stored $\stackrel{ }{\perp}$ deep-frozen in $0 \cdot 1 \mathrm{ml}$ aliquots.

UNLABELLED THYROXINE (FOR STANDARDS) L-thyroxine ( $\mathrm{Na}$ salt) $\mathrm{BDH}$, was used initially but was found to have variable storage properties. 요 Subsequently (on the advice of Dr W. H. C. Walker, $\stackrel{2}{\rightarrow}$ personal communication) thyroxine tablets, $50 \mu \mathrm{g}$ 윽 as sodium thyroxine pentahydrate, were used. Five tablets $^{1}$ were crushed in $15 \mathrm{ml} 0.1 \mathrm{~N} \mathrm{NaOH}$ and made up to $89 \mathrm{ml}$ with $100 \%$ ethanol. After centrifugation to precipitate filler the resulting stock solution, $250 \mu \mathrm{g} / 100 \mathrm{ml}$ as thyroxine (periodically checked by the method of Gemmill, 1955), was stored at $-20^{\circ}$ in $2 \mathrm{ml}$ aliquots. For use a $2 \mathrm{ml}$ aliquot of stock $\mathrm{T}_{4}$ was diluted with ethanol RR to $25 \mathrm{ml}$ to yield a working $\mathrm{T}_{4}$ solution of $20 \mu \mathrm{g} / 100 \mathrm{ml}$. A fresh working stan-o dard was made up for each batch, and appropriate $>$ dilutions were made with ethanol to provide interme-을. diate standards $(10 \cdot 0,5 \cdot 0$, and $2 \cdot 5 \mu \mathrm{g} / 100 \mathrm{ml})$.

\section{ANION EXCHANGE RESIN}

Initially the resin recommended by Murphy (1965), స్ Rexyn 202 (C1-SO ${ }_{4}$, was used. Subsequently twoত other resins were found to be equally satisfactory, AG $2 \times 8$ chloride form 50-100 mesh (Bio-Rad $\frac{\varnothing}{\varnothing}$ Laboratories) and $2 \times$ 8-100 Dowex-2 chloride form $\stackrel{\oplus}{+}$ 50-100 mesh (Sigma). The resin was washed twice $\square$ with distilled water and once with $0.075 \mathrm{M}$ barbitalo buffer pH 8.6 with removal of fines after each wash and then carefully dried.

Each tablet is accurate to $\pm 2.5^{\circ} \%$, which gives an accuracy for the five tablets as $\frac{\sqrt{ } 5 \times 2.5^{2}}{5}$ or $1.1^{\circ}$ 。 
BARBITAL BUFFER

pH 8.6, ionic strength $0.075 \mathrm{M}$, was made up as described by Murphy (1965).

\section{EXTRACTION MIXTURE}

An $80: 20$ mixture by volume of $95 \%$ ethanol : $n$ butanol, stored in a brown bottle at $-20^{\circ}$.

\section{BINDING REAGENT}

A mixture of ${ }^{125} \mathrm{I}$-thyroxine (approximately $5 \mu \mathrm{c}$ ), $2.0 \mathrm{ml}$ of pooled normal serum (stored frozen), $10 \mathrm{mg}$ phenol, and $1 \mathrm{ml}$ propylene glycol was made up to $100 \mathrm{ml}$ with the barbital buffer. This reagent was prepared fresh at least weekly.

\section{Results of Investigations}

\section{EXTRACTION}

The object is to produce a protein-free extract containing as much of the thyroxine as possible. If protein (including thyroxine-binding globulin, TBG) is present in the extract it interferes with the assay because the excess binding protein in the tubes containing extracts of test plasma increases the percentage of $T_{4}$ bound and therefore gives artificially low $T_{4}$ values when the tests are read against the standard curve. Murphy's method (1965) in our hands gave an extract which contained some $70 \%$ of the original $T_{4}$ but also contained protein. This effect is demonstrated in figure 1. Line $A$ is a normal standard curve. Line B is a standard curve in which $0.3 \mathrm{ml}$ of serum extract, prepared as described by Murphy, was added to the standards before drying down. It is apparent that the curve (corrected for the $T_{4}$ content of the serum extract) is markedly depressed, as would be predicted if TBG was present in the extract. Further examination of extracts prepared as described by Murphy showed that most extracts contained some $60 \mathrm{mg}$ of protein per $100 \mathrm{ml}$ of extract (measured by sulphosalicylic acid precipitation) and cellulose acetate electrophoresis showed a protein pattern in the extracts very similar to that of normal serum. ${ }^{1}$

Modified extraction methods have been described which are claimed to increase the recovery of $T_{4}$. These involve the drop-wise addition of serum to $95 \%$ ethanol with continuous stirring (Cassidy, Benotti, and Peno, 1968) or the addition of ammonia to the extraction fluid (Maclagen and Howarth, 1969). We found that neither of these methods produced a protein-free extract and only with the latter procedure could we confirm the increased recovery claimed.

'Since this paper was submitted, Crombag et al have reported (Clin. chim. Acta, 1973, 46, 348) that about $3 \%$ of serum proteins are extracted by a mixture of ethanol, urethanol, and propanol in the propol tions $90: 5: 5$.

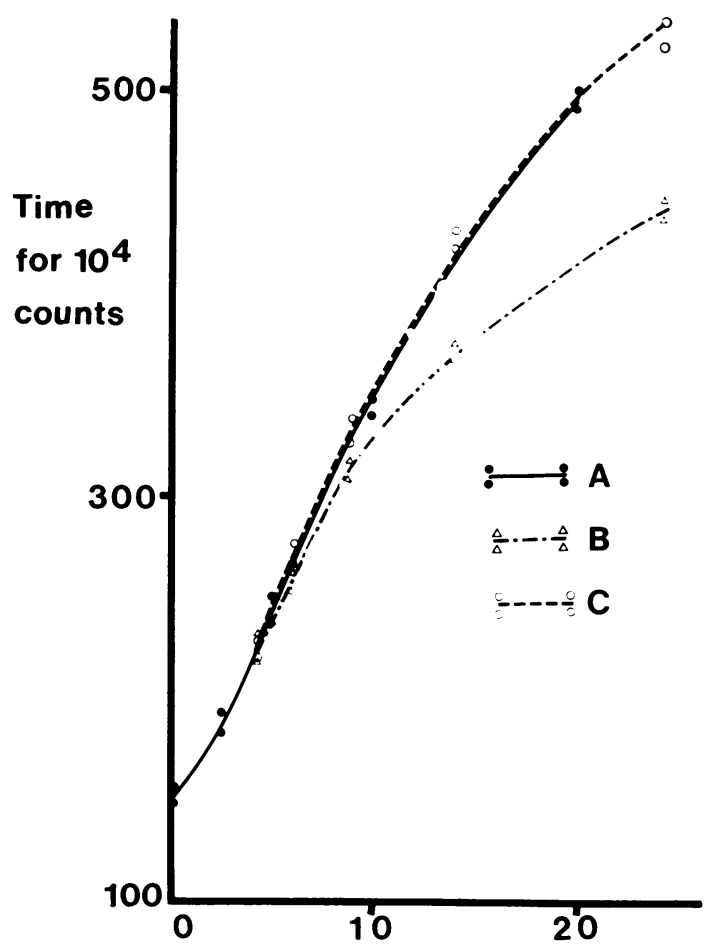

T4 $\mathbf{L g} / 100 \mathrm{ml}$

Fig 1 The effect of serum extract on the standard curve Line $A$, normal standard curve, line $B$, standard curve with $0.3 \mathrm{ml}$ of serum extract containing $4.4 \mu \mathrm{g} \mathrm{T}_{4} / 100 \mathrm{ml}$ prepared as described by Murphy (1965) added to each standard; line $C$, as line $B$ but adding extract prepared by the modified method demonstrating non-interference with the standard curve. The points for curves $B$ and $C$ have been corrected for the $T_{4}$ content of the added extract.

Several methods of solving this problem were investigated, including varying the proportion of extraction fluid to serum, acidifying the extraction fluid, varying the temperature of extraction, vortexing for varying times, heating to $70^{\circ}$ for $15 \mathrm{~min}$ in an attempt to denature the protein, varying the proportions of ethanol and butanol used, extracting with acetone, and pretreating the serum with ether. It was found that most of these manoeuvres produced little or no improvement. However, carrying out the extraction with ethanol in an ice bath at $1^{\circ}$ followed by centrifugation at $3000 \mathrm{rpm}$ for 12 minutes overcame the problem in that the protein content of the extracts was reduced to nil or trace amounts ( $<10 \mathrm{mg} / 100 \mathrm{ml}$ ) which did not affect the standard curve. This is shown by line $\mathrm{C}$ of fig 1 , which is the 
standard curve obtained by adding an extract of serum, prepared as described above, to the standards and correcting for the serum $T_{4}$ level. It is apparent that under these conditions the serum extract does not affect the standard curve. Table I shows the protein content of various extracts prepared at different temperatures.

\begin{tabular}{|c|c|c|c|}
\hline $\begin{array}{l}\text { Extraction Mixture } \\
\text { and Temperature }\end{array}$ & & $\begin{array}{l}\text { Protein in Extract } \\
(\mathrm{mg} / 100 \mathrm{ml})\end{array}$ & $\begin{array}{l}\text { Recovery of } \\
{ }^{125} I T_{4}(\%)\end{array}$ \\
\hline Ethanol $(95 \%)$ & $\begin{array}{l}\text { at } 45^{\circ} \\
\text { at } 18^{\circ} \\
\text { at } 1^{\circ}\end{array}$ & $\begin{array}{r}75 \\
51 \\
<10\end{array}$ & $\begin{array}{l}\overline{75} \\
67\end{array}$ \\
\hline $\begin{array}{l}\text { Ethanol/butanol } \\
90: 10\end{array}$ & at $1^{\circ}$ & - & $72 \cdot 5$ \\
\hline $\begin{array}{l}\text { Ethanol/butanol } \\
80: 20\end{array}$ & $\begin{array}{l}\text { at } 18^{\circ} \\
\text { at } 1^{\circ}\end{array}$ & $\begin{array}{r}55 \\
<10\end{array}$ & $\overline{74} \cdot 5$ \\
\hline $\begin{array}{l}\text { Ethanol/butanol } \\
\text { 50:50 }\end{array}$ & $\begin{array}{l}\text { at } 18^{\circ} \\
\text { at } 1^{\circ}\end{array}$ & $\begin{array}{l}280 \\
140\end{array}$ & $\overline{84 \cdot 4}$ \\
\hline
\end{tabular}

Table I Protein concentrations and $T_{4}$ recoveries for various extraction fluids at various temperatures

Using the modified extraction procedure at $1^{\circ}$ the recovery of $\mathrm{T}_{4}$ was determined as described by Murphy (using ${ }^{125} \mathrm{I}-\mathrm{T}_{4}$ ) with various mixtures of ethanol and butanol. Ethanol $(95 \%)$ alone gave a recovery of $66.8 \%$ (SD $1.4 \%$ ). The addition of butanol to the system improved the recovery but, if the butanol content of the extraction fluid was increased to $50 \%$, protein carry-over became a problem even under the modified extraction conditions, as is shown in table I. We found the best compromise to be a mixture of $80 \%$ ethanol and $20 \%$ butanol, which under the conditions described gave a recovery of $74.5 \%$, SD $1.3 \%$ (23 determinations) without significant extraction of protein. This figure agreed well with the results obtained by measuring the recovery of unlabelled $T_{4}$ added to a myxoedema serum which was then assayed in the usual way, when a mean recovery of $74.7 \%$ (12 determinations) for $T_{4}$ additions ranging from 5 to $20 \mu \mathrm{g} / 100 \mathrm{ml}$ was found. The recovery was slightly affected by the level of $\mathrm{T}_{4}$ added, ranging from $71.5 \%$ for the $20 \mu \mathrm{g} / 100 \mathrm{ml}$ addition to $77.0 \%$ for the $5 \mu \mathrm{g} / 100 \mathrm{ml}$ addition.

\section{BINDING REAGENT AND THE STANDARD CURVE}

We experimented with different concentrations of serum in the binding reagent in order to obtain maximum sensitivity. Sensitivity is here defined (after Ekins, 1968) as the smallest change in concentration of $T_{4}$ that can be reliably detected; it is therefore directly related to the precision of the method. As precision is inversely related to the standard deviation

Sensitivity $\alpha$ precision $\alpha \frac{1}{\mathbf{S D}_{\mathbf{T}_{4}}}$ where $\mathrm{SD}_{\mathrm{T}_{4}}$ is the standard deviation on a test result.
Changes in sensitivity under different assay conditions can therefore be measured by assessing changes in $\mathrm{SD}_{\mathrm{T}_{4}}$. The standard deviation of the test (in terms of $\mu \mathrm{g} / 100 \mathrm{ml}$ ) will depend directly on the standard deviation of the measurement made in counts per second bound (cps), and inversely upon the slope of the standard curve at the point $\vec{\circ}$ where cps is converted to $T_{4}$ concentration. The slope is equal to $\frac{\mathrm{d} y}{\mathrm{~d} x}$ if counts per second bound are plotted as the ordinate $(y)$ and $T_{4}$ as the abscissa $(x)$. Provided that, over the range covered by cps \pm 1SD for any particular $T_{4}$ values, the standard curve is nearly straight, then, as a first approximation,

$$
\mathbf{S D}_{\mathbf{T}_{4}}=\operatorname{SD}_{\boldsymbol{y}} \cdot \frac{\mathrm{d} x}{\mathrm{dy}} \quad \ldots \ldots \ldots \ldots \ldots \ldots \ldots
$$

where $y=\operatorname{cps}$ for a $T_{4}$ value of $x$.

It has been found empirically that in this system

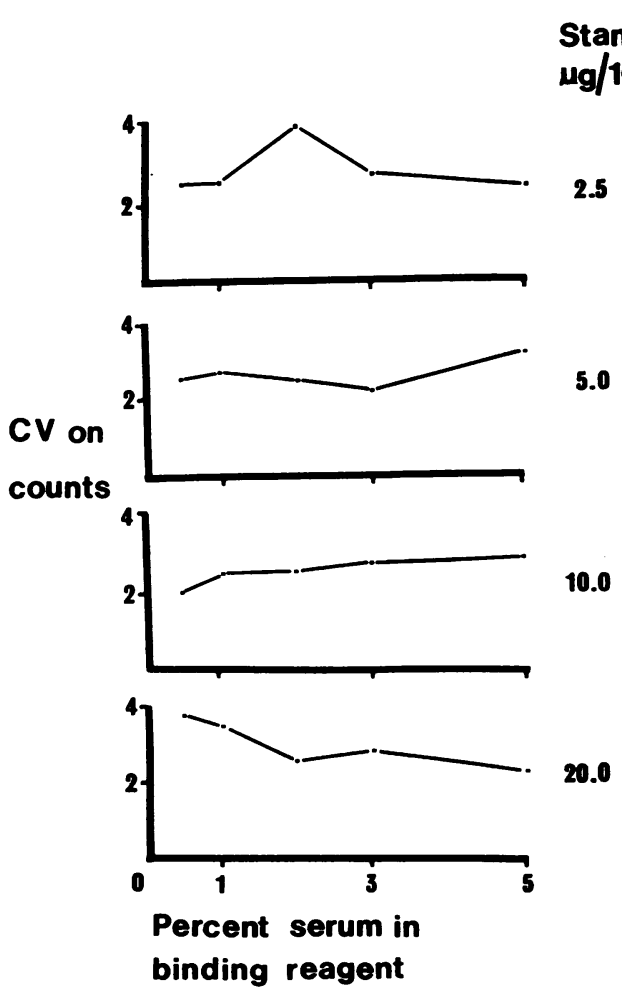

Fig 2 Coefficient of variation of counts bound at various $T_{1}$ concentrations $(2 \cdot 5,5 \cdot 0,10 \cdot 0$, and $20 \cdot 0$ $\mu g(100 \mathrm{ml})$ in $0.5,1.0,2.0,3.0$, and $5.0 \%$ binding reagent). 


\begin{tabular}{|c|c|c|c|c|}
\hline \multirow{2}{*}{$\begin{array}{l}\text { Standard } \\
(\mu \mathrm{g} / 100 \mathrm{ml})\end{array}$} & \multicolumn{4}{|c|}{ Serum Concentration (\%) } \\
\hline & 0.5 & $1 \cdot 0$ & $2 \cdot 0$ & $3 \cdot 0$ \\
\hline $2 \cdot 5$ & $\begin{array}{l}5.8 \\
6.0\end{array}$ & $\begin{array}{l}6.8 \\
6.0\end{array}$ & $\begin{array}{r}8.0 \\
16.0\end{array}$ & $\begin{array}{l}23 \cdot 5 \\
28\end{array}$ \\
\hline $5 \cdot 0$ & $\begin{array}{l}4 \cdot 4 \\
4 \cdot 4\end{array}$ & $\begin{array}{l}4 \cdot 0 \\
5 \cdot 0\end{array}$ & $\begin{array}{l}4 \cdot 6 \\
4 \cdot 0\end{array}$ & $\begin{array}{l}8 \cdot 8 \\
8 \cdot 0\end{array}$ \\
\hline $10 \cdot 0$ & $\begin{array}{l}3.9 \\
4.0\end{array}$ & $\begin{array}{l}3.5 \\
5 \cdot 0\end{array}$ & $\begin{array}{l}3 \cdot 0 \\
4 \cdot 0\end{array}$ & $\begin{array}{l}8.0 \\
6.0\end{array}$ \\
\hline $20 \cdot 0$ & $\begin{array}{l}5 \cdot 5 \\
7 \cdot 0\end{array}$ & $\begin{array}{l}4 \cdot 5 \\
7 \cdot 0\end{array}$ & $\begin{array}{r}7.0 \\
10 \cdot 0\end{array}$ & $\begin{array}{l}3.8 \\
5.0\end{array}$ \\
\hline
\end{tabular}

Table II Comparison of coefficients of variation predicted from formula (upper figure) and determined experimentally (lower figure)

the coefficient of variation (CV) on $y$, ie, $\frac{\mathrm{SD} y}{y} \cdot 100$, remains virtually constant over the relevant range of serum concentrations in the binding reagent (fig 2) and may therefore be written as a constant $\mathbf{k}^{*}$ (which includes not only errors in counting but also all the accumulated errors at the various stages of the method prior to counting); then, again as a first approximation,

$\frac{\mathrm{SD}_{y}}{y}=\mathrm{k}$ and $\mathrm{SD}_{y}=\mathrm{k} . y$ and hence, substituting for $\mathrm{SD}_{y}$ in equation 2 ,

$$
\mathbf{S D}_{\mathbf{T}_{4}}=\mathrm{k} \cdot y \cdot \frac{\mathrm{d} x}{\mathrm{~d} y} \quad \ldots \ldots \ldots \ldots \ldots \ldots \ldots
$$

Although this formula is based on two approximations, it does in fact predict the precision obtainable with different concentrations of binding protein (table II) once the value of $\mathbf{k}$ has been determined experimentally for the particular analytical procedure in use. The standard curves for the different concentrations of binding protein are shown in figure 3.

It should be noted that the precision will vary in different parts of the standard curve because of the variation in slope. However, even if the standard curve were linear (ie, slope constant, therefore $\left.\mathrm{SD}_{\mathrm{T}_{4}}=\mathrm{k} . y\right)$, the coefficient of variation $\frac{\left(\mathrm{SD}_{\mathrm{T}_{4}}\right)}{\mathrm{T}_{4}}$ would still vary at different levels of $T_{4}$ because $T_{4}$ is not directly proportional to $y$.

Where major changes in precision are not expected it may be useful to plot the calibration curve expressing $y$ as a percentage of $y_{z}$ (cps bound for zero addition of $\mathrm{T}_{4}$ ) to allow for changes in $y$ which are simply the consequences of change in $y_{z}$ (such as would occur if the amount of ${ }^{125} \mathrm{I}_{-} \mathrm{T}_{4}$ were raised).

*This applies only to counting for a fixed number of counts, under which circumstance the error at the stage of counting is held constant.

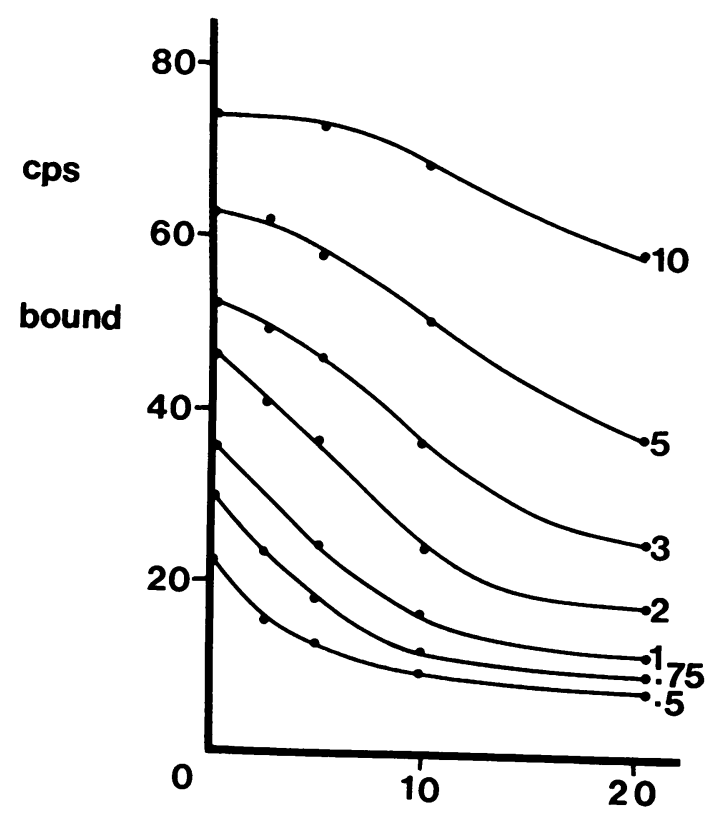

$\mathrm{T}_{4} \mu \mathrm{gg} / 100 \mathrm{ml}$

Fig 3 Standard curves obtained with different concentrations $(\mathrm{ml} / 100 \mathrm{ml})$ of serum in the binding reagent.

Figure 4 shows the results of fig 3 replotted in this way. If such curves are superimposable, they must have the same precision at all points. If they are not superimposable, it is not possible to predict precision from slope with any reliability, and formula 3 should be used

In selecting a standard curve for routine use two important points must be considered. First if, as in this case, the standard curve is not linear throughout its range, it is important that the steep portion of the curve should cover the $T_{4}$ levels of greatest diagnostic importance, ie, the upper and lower limits of normal; these should have the smallest possible SD which means a relatively small count value $(y)$ and a small $\frac{\mathrm{d} x}{\mathrm{~d} y}$, ie, a high $\frac{\mathrm{d} y}{\mathrm{~d} x}$ or high negative slope. Thus with a normal range of 3.5$8.0 \mu \mathrm{g} \mathrm{T} / 1 / 100 \mathrm{ml}$ the curve should be steep and near the $x$ axis over the range $2 \cdot 5-10 \cdot 0$. Secondly, because of competing demands for counter time, unduly long count times should be avoided. If we accept that all samples should be counted to at least 10000 counts (for a $1 \%$ coefficient of variation on 

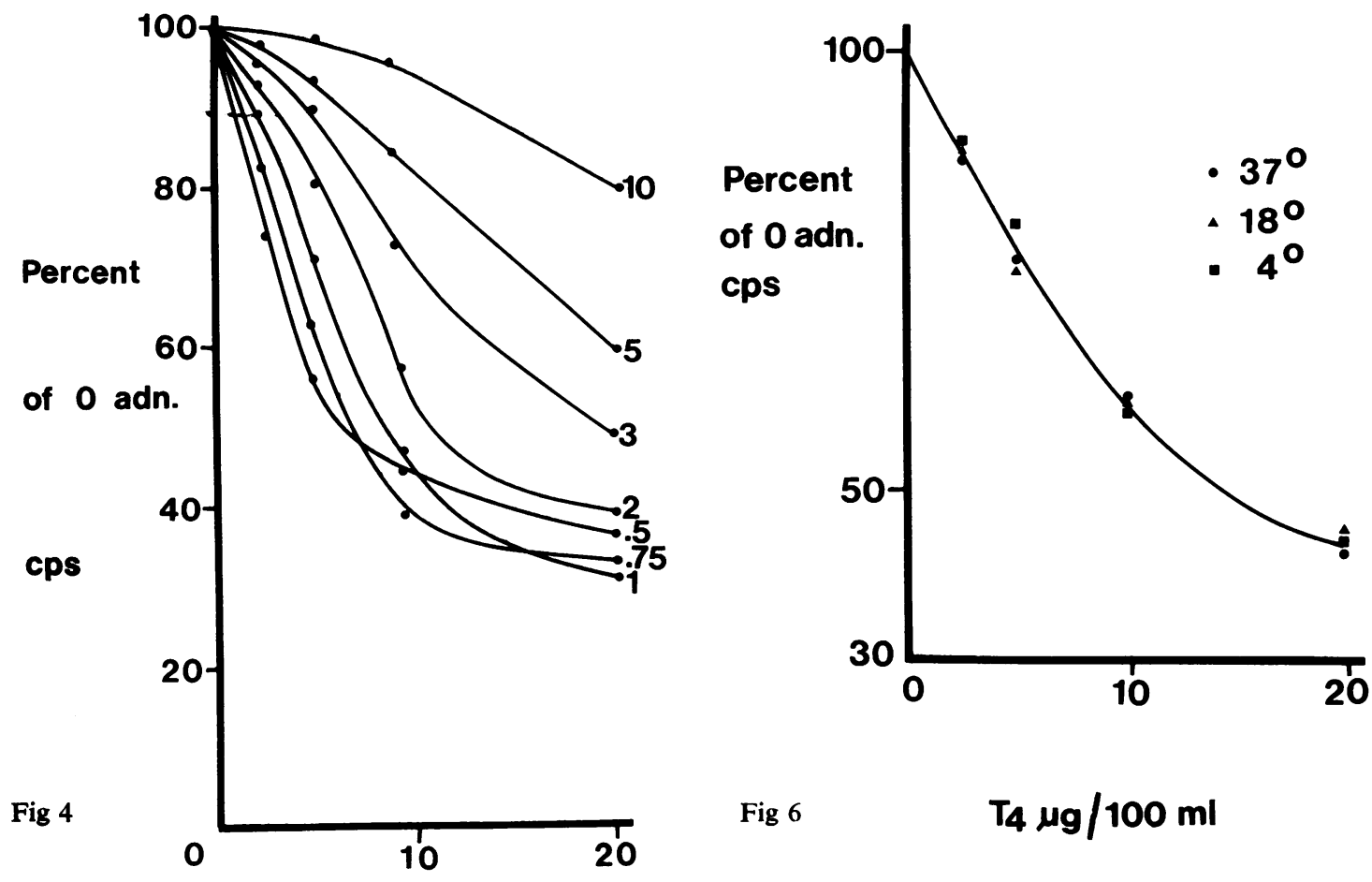

Fig 6

$T_{4} \mu \mathrm{g} / 100 \mathrm{ml}$

T4 ug/100 ml

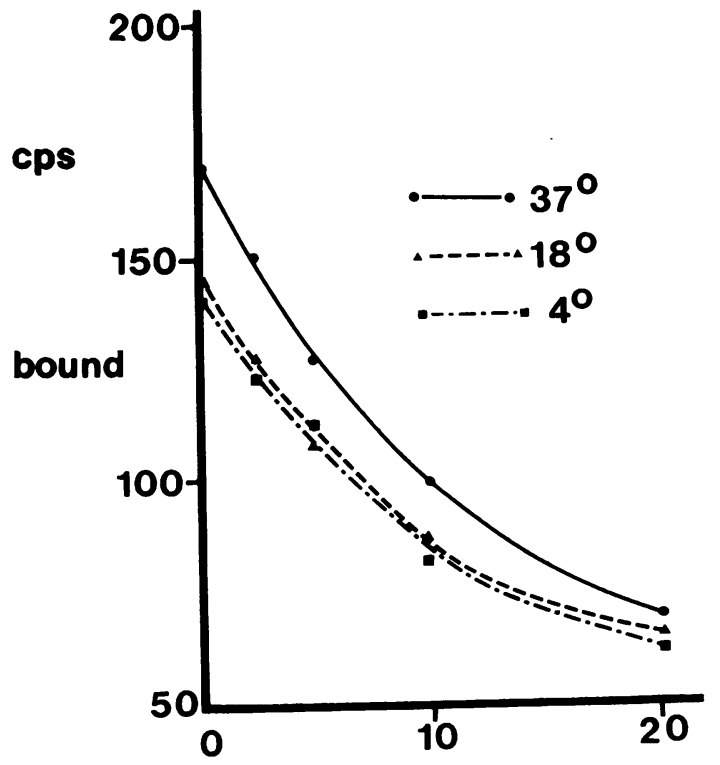

Fig 4 Standard curves obtained with different concentrations ( $\mathrm{ml} / 100 \mathrm{ml})$ of serum in binding reagent with counts bound expressed as a percentage of the zero addition counts bound. ( $O$ adn)

Fig 5 Effect of temperature of equilibration on standard curve.

Fig 6 Effect of temperature of equilibration on standard curve when cps bound is expressed as a percentage of the zero addition value. $(\mathrm{O}$ adn) 
the counting) and that the count time should not exceed 500 seconds then the highest standard should have at least $20 \mathrm{cps}$ bound. The standard deviations for 2.5 and $10 \mu \mathrm{gT}_{4} / 100 \mathrm{ml}$ are shown in table II for different concentrations of binding protein, and it can be seen that the best precision for both levels together is obtained with $1 \%$ serum. The best precision for the two levels separately are at $0.5 \%$ and $2 \%$ for 2.5 and $10 \mu \mathrm{g} / 100 \mathrm{ml}$ respectively. As the $2 \%$ binding protein concentration had the advantage of producing shorter count times, a factor which became progressively more useful as a batch of ${ }^{125} \mathrm{IT}_{4}$ decayed, we have mostly used this concentration despite the loss of precision at low $\mathrm{T}_{4}$ levels.

\section{EQUILIBRATION}

Murphy (1965) recommends that, after incubation at $45^{\circ}$ to promote solution of the extracted thyroxine, equilibration should be allowed to take place in a refrigerator. To investigate the necessity of this low temperature equilibration standard curves were set up and allowed to equilibrate for 15 minutes at $4^{\circ}$, room temperature $\left(18^{\circ}\right)$, and $37^{\circ}$ before the addition of resin. As shown in fig 5 there is little difference between $18^{\circ}$ and $37^{\circ}$, but equilibration at $4^{\circ}$ did

\section{cps bound}

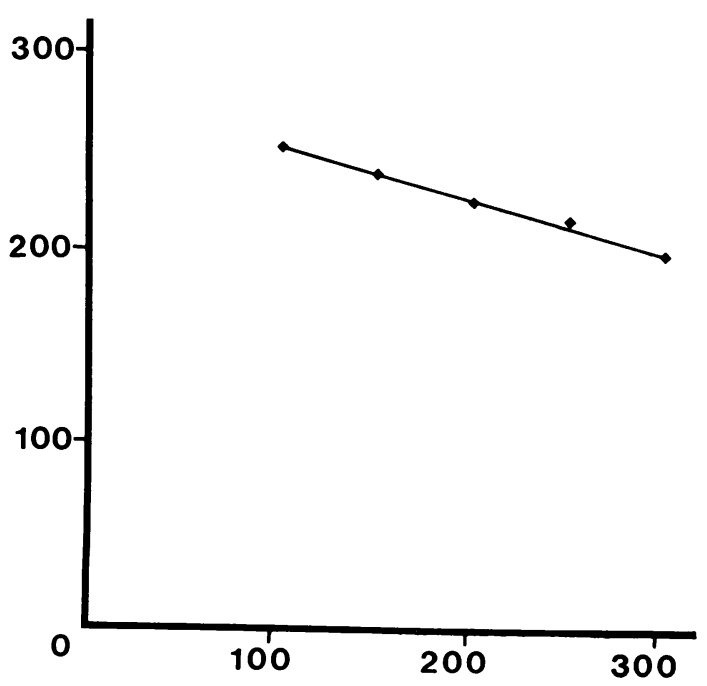

mg of resin added

Fig 7 Effect on cps bound of adding different weights of resin to a zero standard.

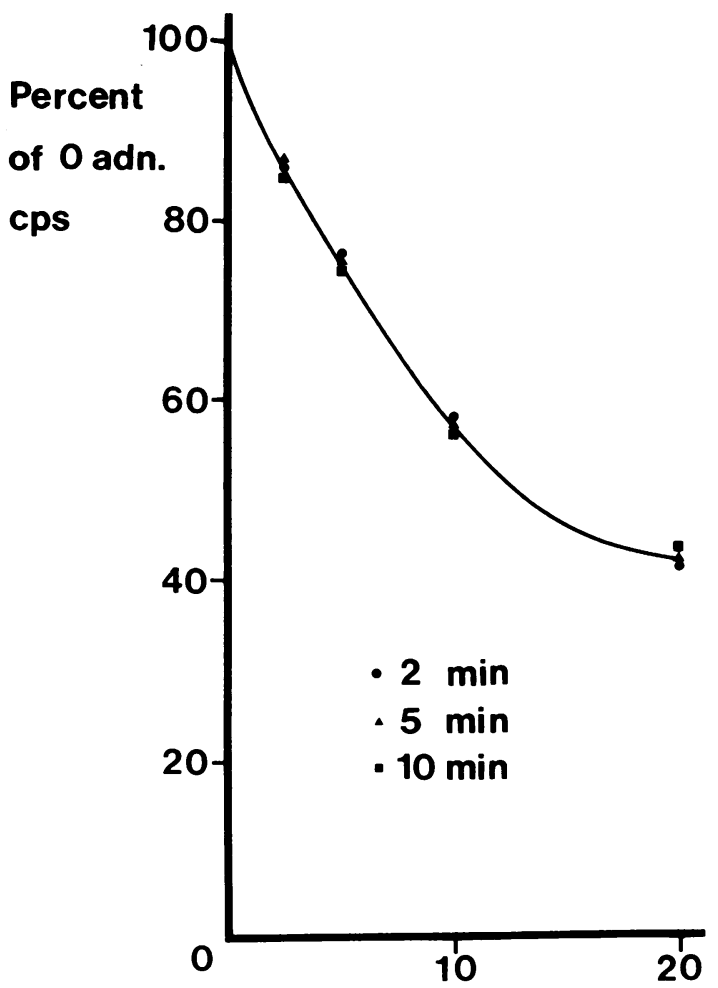

$\mathrm{T}_{4} \mu \mathrm{g} / 100 \mathrm{ml}$

Fig 8 Effect of shaking with resin for different times on standard curve when cps bound are expressed as a percentage of the zero addition value. $(\mathrm{O}$ adn)

result in a standard curve with a slightly greater gradient though with a higher zero addition cps bound. For the reasons explained in the previous section this need not necessarily lead to a more sensitive assay system, and fig 6 shows that, if allowance is made for the different zero addition cps bound values by expressing all counts as a percentage of the counts for zero addition, no difference between the standard curves obtained could be demonstrated. It was therefore decided that for convenience equilibration should be carried out at room temperature.

SEPARATION OF BOUND AND FREE

The resin was dispensed using a glass spoon, the precision of which was found to be $186 \mathrm{mg}$, SD 6.4 , corresponding to a CV of $3.5 \%$. However, because of the relationship between weight of resin added 
and the cps remaining in the supernatant shown in fig 7 , the $3.5 \% \mathrm{CV}$ on the weight of resin added produced only a $0.9 \% \mathrm{CV}$ on the count time, which was considered to be acceptable. After addition of the resin the tubes were stoppered and shaken in a Kahn shaker. Studies of the effect of shaking for different times show that, as shaking is prolonged, not only does the gradient of the standard curve become less, but also the zero addition cps bound falls. When allowance for this latter phenomenon is made by expressing the cps bound as a percentage of the zero addition value (figure 8), it is apparent that the real sensitivity did not change for shaking times varying from two to ten minutes. Another experiment shown in fig 9 demonstrates that a plateau of sensitivity for all the standards is reached after two to four minutes. It was therefore concluded that if all tubes were shaken for five minutes the plateau position would be reached in all tubes and that minor variations in the shaking times between batches would be unimportant; however it is essential for all tubes in the same batch to be shaken for exactly the same time so that tests and standards remain comparable in terms of slope and zero addition value.

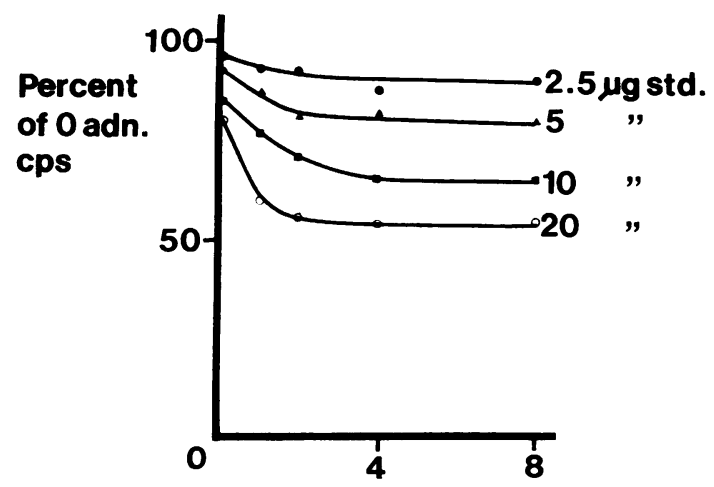

mins in shaker

Fig 9 Effect on cps bound of shaking four standards for different times, expressed as a percentage of the zero addition value. ( $O$ adn $)$

\section{Final Form of Method}

As a result of the experiments described above the following final procedure was adopted.
SERA

A mixture of $0.5 \mathrm{ml}^{1}$ of unknown serum and $1 \mathrm{ml}^{1}$ of extraction mixture, both precooled to $0^{\circ}$, was vortexed for 10 seconds and centrifuged without delay for 12 minutes at $3000 \mathrm{rpm}$. Thereafter $0.3 \mathrm{ml}$ of each supernatant was transferred to another tube and evaporated to dryness in a $45^{\circ}$ water bath in a stream of nitrogen.

\section{STANDARDS}

Of the following dilutions of working standard $0.5 \mathrm{ml}$ was pipetted into tubes in duplicate and $1.0 \mathrm{ml}$ of extraction mixture added: neat, $1 / 2,1 / 4$, and $1 / 8$, giving $T_{4}$ values of $2 \cdot 5,5 \cdot 0,10 \cdot 0$, and $20 \cdot 0 \mu \mathrm{g} / 100$ ml.

After brief vortexing $0.3 \mathrm{ml}$ aliquots were pipetted into other tubes and evaporated in the same way as the serum extracts.

\section{ASSA $Y$}

To each of the tubes containing the dried-down extracts or standards and to two blank tubes (experiments having shown that these gave the same values as tubes in which a mixture of ethanol and extraction mixture had been dried down), $1 \mathrm{ml}$ of binding solution was added. The tubes were briefly vortexed, then placed in a $45^{\circ}$ water bath for eight minutes and vortexed again to ensure complete solution of the dried residues. They were then left at room temperature for at least 15 minutes.

One spoonful of resin was then quickly added to each tube and the tubes were shaken together for five minutes in a Kahn shaker; $3 \mathrm{ml}$ of barbital buffer was then added without delay to each tube using a syringe pipette, and each tube then vortexed for a few seconds. After at least three minutes, when the resin had sedimented, $2 \mathrm{ml}$ aliquots of supernatant were pipetted into $2.5 \mathrm{ml}$ counting tubes and counted to 10000 counts in a well-type scintillation counter. Results were read from the standard curve, corrected for $\mathbf{7 4 . 5} \%$ extraction, and converted to thyroxine-iodine.

Commercial control sera (normal and thyrotoxic) and repeats from the previous batch were included in each batch for quality control purposes.

\section{Precision of Method}

\section{WITHIN-BATCH PRECISION}

Experience with the modified method for over a year has shown that the within-batch $\mathrm{CV}$ for $\mathrm{T}_{4} \mathrm{I}$ levels of 4 to $10 \mu \mathrm{g} / 100 \mathrm{ml}$ is virtually constant at a level just above or just below $5 \%$. It must be stressed that these figures were obtained from the results of assays

${ }^{1}$ Volumes can be reduced to $0.25 \mathrm{ml}$ of serum and $0.5 \mathrm{ml}$ of solvent if it is not intended to analyse duplicate aliquots of the extract. 
performed by duplicate extraction of the same serum and not on duplicate samples from the same extract as has been reported by other workers (Murphy, 1965; Maclagen and Howorth, 1969).

To make an analysis of variance it is convenient that the observed $C V$ in terms of $T_{4} I$ be expressed in terms of the $\mathrm{CV}$ of the observed variable, ie, cps bound. This is not the same as the CV in terms of $T_{4} I$ because of the form of the standard curve. Analysis of the cps bound figures which were used to calculate the $\mathrm{T}_{4} \mathrm{I}$ levels for the within-batch $\mathrm{CV}$ of $5.0 \%$ showed that the CV in terms of cps bound was $2.55 \%$, ie, a total variance of 6.50 .

In order to identify the components of this total variance, the variance of each stage of the method was examined. The results are shown in table III which demonstrates that the sum of the identified variances is 5.42 , leaving an unidentified (residual) variance of only 1.08. Table III also shows that the major contributor to the variance is the extraction step and it was concluded that none of the other steps contributed sufficiently to justify further attempts to improve on them. The extraction step could be improved by determining the individual recovery for each test serum using labelled $T_{4}$, but this was not considered to be worth the extra work involved.

\begin{tabular}{|c|c|c|}
\hline Stage of Assay & $\begin{array}{l}\text { Coefficient of } \\
\text { Variation }(\%)\end{array}$ & $\begin{array}{l}\text { Variance on } \\
\text { Counts }\left(-\mathrm{CV}^{2}\right)\end{array}$ \\
\hline \multicolumn{3}{|c|}{ Pipetting $0.5 \mathrm{ml}$ serum $)^{1}$} \\
\hline $\left.\begin{array}{l}\text { Adding } 1.0 \mathrm{ml} \\
\text { extraction fluid }\end{array}\right\}$ & 0.34 & $0 \cdot 11$ \\
\hline Extracting plasma & 1.66 & $2 \cdot 76$ \\
\hline Pipetting $0.3 \mathrm{ml}$ of extract & 0.45 & $0 \cdot 20$ \\
\hline $\begin{array}{l}\text { Drying down } \\
\text { Adding } 1.0 \mathrm{ml}\end{array}$ & 0.46 & $0 \cdot 21$ \\
\hline $\begin{array}{l}\text { binding reagent } \\
\text { Adding } 3.5 \mathrm{ml} \\
\text { buffer }\end{array}$ & 0.36 & $0 \cdot 13$ \\
\hline $\begin{array}{l}\text { Adding resin } \\
\text { Pipetting } 2.0 \mathrm{ml}\end{array}$ & 0.90 & 0.81 \\
\hline for counting & 0.45 & $0 \cdot 20$ \\
\hline Counting sample & 1.00 & 1.00 \\
\hline $\begin{array}{l}\text { Total identified } \\
\text { variance (and CV) }\end{array}$ & $(2 \cdot 33)$ & $5 \cdot 42$ \\
\hline $\begin{array}{l}\text { Actual variance (and CV) } \\
\text { Residual variance }\end{array}$ & $(2 \cdot 55)$ & $\begin{array}{l}6.50 \\
1.08\end{array}$ \\
\hline
\end{tabular}

Table III Analysis of variance

${ }^{1}$ Combined operations

'Value given for counting variance is theoretical on the basis of 10000 counts, in practice the CV on the counts was often up to $1.5 \%$, corresponding to a variance of $\mathbf{2 . 2 5}$ and thus largely accounting for the residual variance.

BETWEEN-BATCH PRECISION

The between-batch $\mathrm{CV}$ for normal and thyrotoxic sera was found to be $8-9 \%$. For hypothyroid sera the
CV was greater but the SD did not rise above 0.5 $\mu \mathrm{g} / 100 \mathrm{ml}$. The greater between-batch variance includes variations in the standards which do not affect precision within a single batch; these variations will be similar to those of the tests except that they exclude errors due to variable recovery, but include errors in making up the working standard from stock standard, and also day-to-day variation in the performance of the counting equipment used during these investigations (which was found over a period to give considerably less precision in counting than the $1 \% \mathrm{CV}$ expected on theoretical grounds).

\section{Discussion}

Using the modified method it was found that both the within-batch and between-batch precision were considerably improved. The original method (Murphy, 1965) in our hands gave a within-batch coefficient of variation for normal and thyrotoxic sera of about $12 \%$, with which the within-batch CV of $5.0 \%$ using the modified method compares very favourably. Similarly the between-batch CV was about $20 \%$ for the original method as compared with $8-9 \%$ for the modified method. The between-batch $\mathrm{CV}$ that we found using the original method is not strictly comparable with the between-batch CV reported by Murphy (1965) of $10 \%$, as our figures are derived from single assays in each batch whereas Murphy's figures were apparently based on the mean of duplicate assays of the same extract in the same batch. Other workers (Nakajima, Kuramochi, Horiguchi, and Kubo, 1966; Kennedy and Abelson, 1967; Siersbaek-Nielsen, 1967; Maclagen and Howorth, 1969) have described modified methods giving between-batch coefficients of variation of $10 \%$ or more, but as their methods usually involve duplicate within-batch determinations we suggest that the modified method here described, which gives rather better precision using only single determinations on each test serum, is the method of choice. Ekins, Williams, and Ellis (1969) have described a modified dual isotope method which allows for individual recoveries to be performed on each test serum. The mean within- and between-batch coefficients of variation reported by these workers were 4.68 and $8.35 \%$ respectively, which are very similar to the figures found for the method reported here. Using the modified method a single technician can produce final answers on a batch of $\mathbf{3 0}$ sera in five hours or less.

From time to time batches of results were obtained which were obviously wrong. In nearly every case the cause was traced to the deterioration on storage of either the stock standard or the radioactive thyroxine, and in our experience these are the two 
factors most likely to cause excessive between-batch variation.

We would like to thank Mrs D. Fisher for her very able technical assistance in the performance of the thyroxine assays and Professor J. C. Shepherdson for advice on the mathematics.

\section{References}

Cassidy, C. E., Benotti, J., and Peno, S. (1968). Clinical evaluation of the determination of thyroxine iodine. J. clin. Endocr., 28, 420-421.

Ekins, R. P. (1960). The estimation of thyroxine in human plasma by an electrophoretic technique. Clin. chim. Acta, 5, 453-459.

Ekins, R. P. (1968). Problems of sensitivity with special reference to optimum conditions; concentrations of tracer and antiserum, time and temperature of incubation, volume of incubation, etc. In Protein and Polypeptide Hormones, part 3, edited by $\mathbf{M}$. Margoulies, p. 672. Excerpta Medica Foundation, Amsterdam.
Ekins, R. P., Williams, E. S., and Ellis, S. (1969). The sensitive and precise measurement of serum thyroxine by saturation analysis (competitive protein binding assay). Clin. Biochem., 2, 253-288.

Gemmill, C. L. (1955). The apparent ionization constants of the phenolic hydroxyl groups of thyroxine and related compounds. Arch Biochem., 54, 359-367.

Kennedy, J. A., and Abelson, D. M. (1967). Determination of serum thyroxine using a resin sponge technique. J. clin. Path., 20, 89-94.

Maclagen, N. F., and Howorth, P. J. N. (1969). Thyroid function studies using resin uptake of radioactive thyronines from serum and total thyroxine assay: the free thyroxine index. Clin. Sci., $37,45-60$.

Murphy, B. E. P. (1965). The determination of thyroxine by competitive protein binding analysis employing an anion-exchange resin and radiothyroxine. J. Lab. clin. Med., 66, 161-167.

Murphy, B. E. P., and Pattee, C. J. (1964). The determination of thyroxine utilising the property of protein binding. J. clin. endocr., 24, 187-196.

Nakajima, H., Kuramochi, M., Horiguchi, T., and Kubo, S. (1966). A new and simple method for the determination of thyroxine in serum. J. Clin. Endocr., 26, 99-103.

Siersbaek-Nielsen, K. (1967). Determination of serum thyroxine: the diagnostic value in thyroid diseases. Acta med. scand., 181, 327-333. 